60. L. rufus. Charlton, U. S., California, Canada. B.M. 61. L. maculatus. Mexico, New Orleans.

\title{
17. Caracal.
}

62. Caracal melanotis. South, Western, and Eastern Africa. B.M.

XLIII.-A List of Butterfies, with Descriptions of new Species, from the Andaman Islands. By W.C. Hewitson, F.L.S.

The kindness of Mr. Higgins has enabled me to give the following list of butterflies, and to add the new species to my collection. They were sent to him by Captain Wimberley, and are in excellent condition.

Papilio Charicles, n. sp.

\section{Mavo. A very distinct and} beautiful species, figured and described by Mr. W. S. Atkinson in the 'Proe. Zool. Soc.' for 1873.

— Eurypilus.

- - Agamemnon.

- Pammon.

- Antiphates.

_ Coon, var. Doubledayi.

Pieris Nadina.

Hebomoia Glaucippe.

Eronia Valeria.

Callidryas Chryseis.

- Crocale. Pomona.

Terias Hecabe. Harina.

Thestias Pyrene.

Euploea andamanensis. Figured by Mr. Atkinson on the same plate as P. Mayo.

Danais Aglea.

Hestia Agamarschana. All the examples in this collection are much darker than Felder's figure.

Cynthia Deione.

Messaras Erymanthis.

Atella Alcippe.

Cirrhochroa Tyche.

Cethosia Biblis. There is a very interesting female variety of this species, with a large white spot on the anterior wing; the posterior cream-colour.

Vanessa cardui.

Junonia Enone.

Cyrestis Cocles. For delicacy of colour these are some of the most beautiful things I have ever seen.

Neptis aceris.

- Pampanga. Cnacalis, n. sp.

Diadema Bolina.

Adolias Teuta.

- Acontius, n. sp. Cibaritis, n. sp.

Minetra Sylvia.

Kallima Philarchus.

Doleschallia Bisaltide.

Amathusia Phidippus.

Discophora Ogina.

Cyllo Leda.

Melanitis Cottonis, n. sp.

Eurytela Horsfieldii.

Mycalesis Samba.

Amblypodia Amytis.

Aphnæus Lohita.

Loxura Atymnus.

Anops Thetis.

Lycæna Elpis.

Ismene Chromus.

\section{Papilio Charicles.}

Upperside. Female dark brown. Anterior wing semi- 
transparent, brown-white, palest below the median nervure: the margins, the base (which is marked by a triangular carmine spot), longitudinal rays in the cell, the nervures, and lines between them dark brown. Posterior wing marked before the middle by five white spots-one (the largest) in the cell, one between it and the costal margin, two between it and the inner margin, and one (the fifth) below the cell: the inner margin, which is marked by a black spot, and a series of six spots on the outer margin all dull carmine: the outer margin dentate, deeply sinuated between the nervures; the tail spatulate, its outer half white, tinted with carmine.

Underside as above, except that the posterior wing has four red spots at the base and seven white spots before the middle.

Exp. 5 inches.

This singular species, although reminding one at first sight of $P$. Coon, is so like P. Memnon (var. Achates, Cramer) that but for the long and narrow posterior wing it might easily be mistaken for that species.

\section{Neptis Cnacalis.}

Upperside dark brown. Anterior wing with the longitudinal spot from the base orange, unusually long, reaching considerably below the middle of the wing, unbroken: crossed beyond the middle by six spots of orange, the middle two spots minute, and outside of this by a narrow band of lilacwhite. Posterior wing crossed before the middle by a broad band of white.

Underside. Anterior wing as above, except that the band and spots are much larger and rufous white, the apex greywhite, and that there are some grey spots near the costal margin. Posterior wing with the base brown, undulated with grey: below the band lilac-grey, traversed by two bands of brown; the outer margin brown.

Exp. $1 \frac{1}{2} \frac{1}{0}$ inch.

On the underside this species resembles N.Hordonia; its anterior wing is unusually prolonged at the apex.

\section{Adolias Acontius.}

Upperside. Female dark rufous brown. Anterior wing with the usual spots in the cell: crossed from the middle of the costal margin to a little beyond the first median nervule (towards the anal angle) by a band (broader as it proceeds) of seven white spots- the first minute, the last, which is below the median nervule, small : a band of three spots, commencing nearer the apex, joins the band just described at its fourth 
spot: crossed towards the outer margin by a series of black pyramidal spots, bordered inwardly (between them and the white band) by lilac; the last black spot near the anal angle bordered on both sides with lilac. Posterior wing crossed beyond the middle by a broad lilac band, irrorated with white and bordered outwardly by a series of lunular black spots, which have below them hastate lilac spots.

Underside lilac-white. Anterior wing with the bands as above, bordered by pale ochreous brown. Posterior wing with five subbasal spots, bordered with black; the transverse band indistinct, except near the costal margin, where it has a rufous border on both sides.

Exp. $3 \frac{1}{10}$ inches.

\section{Adotias Cibaritis.}

Upperside. Female dark rufous brown. Both wings with the usual spots in and below the cell: both crossed beyond the middle, from the costal margin of the anterior wing to the anal angle of the posterior wing, by a broad band of white divided by the nervures, sinuated deeply on its inner margin at its fourth spot, bordered outwardly by a series of hastate black spots crowned with lilac. Anterior wing with a small white spot between the band and the apex.

Underside pale green. Both wings with the bands and spots as above, bordered inwardly with black.

Male like the female, except that the white band of the posterior wing is narrower, and on the underside bordered on both sides with black spots.

\section{Exp. ơ $2 \frac{17}{20}$, \& $3 \frac{1}{2}$ inches.}

This is the largest known species of the Trigerta group, to which it belongs.

\section{Melanitis Cottonis.}

Upperside. Male dark red-brown. Both wings with the outer margins rufous. Anterior wing with the costal margin lilac-blue.

Underside as above, undulate with grey, the outer margins broadly undulate with grey and brown. Anterior wing with a large triangular grey spot, undulate with brown near the apex. Posterior wing with a white spot near the middle of the costal margin.

Female like the male, except that it is much larger and paler, and that the anterior wing has on its upperside some grey spots on the costal margin.

Exp. $\delta 2 \frac{1}{2}$, $+3 \frac{1}{10}$ inches.

I prefer to consider this a distinct species rather than to place it as a variety of $M$. undularis. Both sexes are alike, are without spots, and have a broad rufous margin. 


\section{$2 \mathrm{BHL}$ Biodiversity Heritage Library}

Hewitson, William C. 1874. "XLIII.-A list of butterflies, with descriptions of new species, from the Andaman Islands." The Annals and magazine of natural history; zoology, botany, and geology 14, 356-358.

https://doi.org/10.1080/00222937408680983.

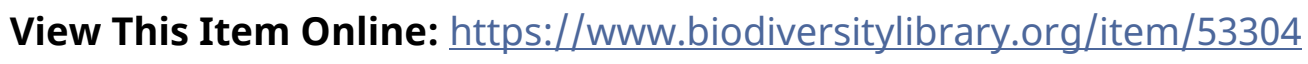

DOI: https://doi.org/10.1080/00222937408680983

Permalink: https://www.biodiversitylibrary.org/partpdf/51193

\section{Holding Institution}

Smithsonian Libraries

\section{Sponsored by}

Smithsonian

\section{Copyright \& Reuse}

Copyright Status: Public domain. The BHL considers that this work is no longer under copyright protection.

This document was created from content at the Biodiversity Heritage Library, the world's largest open access digital library for biodiversity literature and archives. Visit BHL at https://www.biodiversitylibrary.org. 